\title{
Studi Efektivitas Program Akselerasi di SMU Surakarta
}

\author{
Munawir Yusuf \\ Prodi PLB FKIP UNS, E mail : munawir_uns@yahoo.co.id
}

\begin{abstract}
Abstrak: Penelitian ini dilaksanakan dengan tujuan: 1) Untuk mengetahui gambaran secara utuh penyelenggaraan program akselerasi di SMA, 2) Untuk mengetahui efektivitas rekrutmen calon peserta program akselerasi, 3) Untuk mengetahui tingkat motivasi berprestasi siswa akselerasi, 4) Untuk mengetahui dampak posit dan negatif terhadap kepribadian siswa, 5) perbedaan sikap guru terhadap penyelenggaraan program akselerasi antara guru yang mengajar di kelas akselerasi dengan yang tidak mengajar di kelas akselerasi. Pendekatan penelitian yang digunakan adalah deskriptif kuantitatif dan kualitatif. Dua kelas peserta program akselerasi sejumlah 59 siswa semuanya dijadikan subyek penelitian, sementara untuk perbandingan diambil satu kelas program reguler. Hasil menunjukkan bahwa: 1) Secara umum manajemen penyelenggaraan program akselerasi di SMAN Surakarta, termasuk kategori baik; 2) Proses rekruitmen angkatan pertama masih belum memenuhi standar ideal berdasarkan kriteria IQ, CQ, dan TC yang dipersyaratkan. Sedangkan dukungan data akademik lain seperti NEM, Raport, dan skor tes akademik, relatif sudah cukup baik; 3) Motivasi berprestasi siswa akseleran kelas A lebih tinggi dari kelas B dengan perbandingan $72 \%$ dibanding $68 \%$, namun skor gabungan seluruh peserta (59 siswa) menunjukkan bahwa antara yang memiliki motivasi berprestasi tinggi dengan yang sedang proporsinya seimbang yaitu masing-masing $50 \%$; 4) Efektivitas program akselerasi dilihat dari aspek dampak terhadap berapa aspek kepribadian (kepercayaan dan konsep diri siswa), ditemukan bahwa lebih dari $60 \%$ siswa akselerasi kelas A berdampak positif, 32\% negatif (menurun), dan $8 \%$ tetap. Sementara untuk kelas B lebih dari $80 \%$ positif, $12 \%$ negatif (menurun) dan $8 \%$ tetap; 5) Efektivitas program akselerasi dilihat dari aspek guru, dapat disimpulkan bahwa guru-guru yang mengajar di kelas akselerasi memiliki sikap yang lebih positif terhadap program akselerasi dibandingkan dengan guruguru yang mengajar di kelas regular.
\end{abstract}

Kata kunci : anak berbakat dan program akselerasi

Abstract: This research is conducted with the purposes of 1) to get a thorough description of accelerated program in SMAN Surakarta, 2) To know the effectiveness of recruitment of prospective students in accelerated program in SMA Surakarta, 3) To know the degree of achievement motivation of accelerated students, 4) to know the positive and negative impacts on students' personality, 5) To get the gap between the attitudes of teachers who teach at accelerated program with that of teachers who don't. This research combines the qualitative and quantitative description. The subject is two classes of accelerated program ; whereas one class of regular program is taken as a comparison 1) Generally, the management of accelerated program in SMAN X Surakarta is considered good, 2) In terms of recruitment process, a few students in the first batch do not meet the ideal standard, e.g. the IQ, CQ and TC score test do net meet the required minimum standard. On the other hand, the score of NEM, Report and acdemic test is quite satisfactory to meet the entrance qualification, 3) In terms of achievement motivation aspect, class A has relatively higher motivation than class $B ; 72 \%$ compared to $68 \%$, however the joint score of those who have high motivation and moderate motivation shows balance proportion, i.e. 50\%, 4) The effectiveness of accelerated program measured from the impact towards personal aspects (self-confidence and selfconcept) shows that in class A more than $60 \%$ shows positive impact and $32 \%$ shows negative impact, and $8 \%$ remains the same. In class $\mathrm{B}, 80 \%$ shows positive impact, $12 \%$ shows negative impact and $8 \%$ remains the same, 5 ) In terms of teachers, those who teach in accelerated program show more positive attitude toward the accelerated program, compared to those who don't.

Key words: gifted children and accelerated 


\section{Pendahuluan}

Pemerintah Republik Indonesia melalui Menteri Pendidikan Nasional pada tahun 2000 telah mencanangkan program percepatan belajar untuk SD, SLTP dan SMA yang kemudian dikenal dengan program akselerasi. Selanjutnya tahun pelajaran 2001/2002 Direktorat Pendidikan Luar Biasa telah menetapkan kebijakan untuk melakukan sosialisasi tentang program akselerasi terhadap sekolah-sekolah yang mengajukan proposal di beberapa provinsi di Indonesia.

Program akselerasi adalah program percepatan belajar yang disediakan kepada peserta didik yang memiliki kemampuan dan kecerdasan luar biasa. Program ini dimungkinkan karena halhal sebagai berikut : (1) UU Nomor 20 Tahun 2003 tentang Sistem Pendidikan Nasional antara lain mengamanatkan bahwa setiap peserta didik berhak menyelesaikan pendidikan lebih awal dari waktu yang ditentukan. Dalam UU tersebut istilah yang digunakan adala warga negara yang memiliki potensi kecerdasan dan bakat istimewa. Penggunaan istilah potensi kecerdasan dan bakat istimewa ini berkait erat dengan latar belakang teoretis yang digunakan. Potensi Kecerdasan berhubungan dengan kemampuan intelektual, sedangkan bakat tidak hanya terbatas pada kemampuan intelektual, namun juga beberapa jenis kemampuan lainnya seperti yang disebut oleh Gardner (1993) dengan teorinya yang dikenal dengan teori Multiple Intelligences yaitu, kecerdasan linguistik, kecerdasan musikal, kecerdasan spasial, kecerdasan logikalmatematikal, kecerdasan kinestetik, kecerdasan intrapersonal dan kecerdasan interpersonal.

Pengertian potensi kecerdasan dan bakat istimewa dalam program percepatan belajar ini dibatasi hanya pada kemampuan intelektual umum. Menurut Buku Pedoman Penyelenggaraan Program Percepatan Belajar Bagi Siswa Berbakat Akademik, Drektorat Pembinaan Sekolah Luar Biasa, Depdiknas Jakarta (2006), dimuat dalam http://www.ditplb.or.id ada dua acuan yang bisa digunakan untuk mengukur kemampuan intelektual umum, yaitu acuan unidimensional dan acuan multidimensional. Acuan unidimensional merupakan pendekatan yang dikembangkan oleh Terman, sedangkan multidimensional merupakan pendekatan yang dikembangkan oleh Renzulli.
Untuk pendekatan unidimensional, kriteria yang digunakan hanya semata-mata berdasarkan pada skor IQ. Secara operasional, batasan kemampuan intelektual umum yang digunakan adalah IQ 140 dari Skala Wechsler. Sedangkan untuk pendekatan multidimensional, kriteria yang digunakan lebih dari satu. Dalam hal ini, batasan yang digunakan adalah kemampuan umum pada taraf cerdas (ditetapkan skor IQ 125 ke atas dari Skala Wechsler), dimensi kreativitas kategori cukup (ditetapkan skor CQ dalam nilai baku cukup) dan pengikatan diri terhadap tugas kategori baik (ditetapkan skor TC dalam kategori nilai baku baik).

Pro dan kontra tentang penyelenggaraan program akselerasi masih sering muncul. Bagi yang sependapat, mereka beralasan bahwa secara hukum memang dimungkinkan dan mereka memiliki hak untuk itu, juga secara empiris membuktikan bahwa hasil belajar anak-anak peserta program akselerasi tidak kalah dengan hasil belajar anak-anak yang mengikuti program reguler. Sementara itu bagi yang kurang sependapat cenderung beralasan pada dampak negatif dari program akselerasi, misalnya kekhawatiran terjadinya split dalam perkembangan psikososial anak yang tidak sejalan dengan perkembangan kognitifnya. Juga kekhawatiran terjadinya eksklusifisme dalam pendidikan sehingga dapat mempengaruhi perkembangan kepribadian di masa yang akan datang.

Pemerintah memberikan rambu-rambu agar bagi sekolah yang menyelenggarakan program akselerasi dapat memperhatikan dan menanggulangi kemungkinan dampak negatif dari program akselerasi. Rambu-rambu itu antara lain dituangkan dalam kebijakan Direktorat Pendidikan Luar Biasa (Nasichin, 2004), yang mencakup antara lain: 1) pengaturan perizinan, 2) pendataan dan informasi, 3) kurikulum, 4) evaluasi belajar, 5) supervisi dan monitoring, dan 6) pengendalian dan evaluasi penyelenggaraan. Selanjutnya untuk menjaga agar manajemen program akselerasi tidak menyimpang dari aturan yang ada, dilakukan pembinaan yang bersifat pemberdayaan yang meliputi: 1) pembinaan konsepsi kelembagaa, 2) sarana dan prasarana, 3) pembina ketenagaan, dan 4) konsultasi manajemen. 
Pertanyaan yang muncul adalah setelah sekian lama program akselerasi digulirkan, sesungguhnya persoalan mana yang bisa dijawab dari program ini. Apakah memperkuat atas pendapat bagi mereka yang mendukung atau pro terhadap penyelenggaraan program akselerasi, atau sebaliknya memperkuat kekhawatiran-kekhawatiran dari mereka yang cenderung kurang setuju terhadap program akselerasi. Pertanyaan ini penting diajukan karena pendidikan memang tidak hanya menyangkut hak azasi yang paling mendasar, akan tetapi pendidikan juga diarahkan untuk mampu membentuk kepribadian dan membangun manusia seutuhnya sesuai dengan nilai-nilai Pancasila dan UUD 1945. Karena itulah maka kajian secara empirik atas keefektifan penyelenggaraan program akselerasi ini dilakukan.

Berdasarkan latar belakang pemikiran di atas maka dalam penelitian ini dirumuskan masalah sebagai berikut: 1) Bagaimana gambaran manajemen penyelenggaraan program akselerasi di SMA?, 2) Bagaimana efektivitas rekruitmen calon peserta program akselerasi di SMA Surakarta berdasarkan criteria Inteligence Quotient (IQ), Creativity Quotient (CQ) dan Task Commitment (TC), 3) Bagaimana efektivitas program akselerasi dilihat dari motivasi berprestasi peserta program akselerasi di SMA Surakarta? 4) Apakah dampak positif dan negatif program akselerasi terhadap beberapa aspek kepribadian peserta program? 5) Bagaimana efektivitas program akselerasi dilihat dari perspektif guru, baik guru yang mengajar di kelas akselerasi maupun yang tidak mengajar di kelas akselerasi.

Mengacu pada perumusan masalah di atas maka penelitian ini dilaksanakan dengan tujuan untuk mengetahui tentang: 1) Gambaran manajemen penyeleng garaan program akselerasi di SMA, 2) Efektivitas rekruitmen calon peserta program akselerasi di SMA Surakarta berdasarkan criteria Inteligence Quotient (IQ), Creativity Quotient (CQ) dan Task Commitment (TC), 3) Efektivitas program akselerasi dilihat dari motivasi berprestasi peserta program akselerasi di SMA, 4) Dampak positif dan negatif program akselerasi terhadap beberapa aspek kepribadian peserta program, dan 5) Efektivitas program akselerasi dilihat dari perspektif guru, baik guru yang mengajar di kelas akselerasi maupunyang tidak mengajar di kelas akselerasi.

\section{Kajian Literatur}

\section{Pengertian Anak Berbakat}

Dalam Undang Undang Sistem Pendidikan Nasional, anak berbakat dikenal sebagai mereka yang memiliki potensi kecerdasan dan bakat istimewa. Dalam berbagai literature, anak berbakat atau sering disebut 'gifted and talented' adalah mereka yang diidentifikasikan oleh orangorang yang berkualifikasi profesional memiliki kemampuan luar biasa dan mampu berprestasi tinggi. Anak-anak ini membutuhkan program pendidikan terdiferensiasi dan/atau pelayanan di luar jangkauan program sekolah reguler agar dapat merealisasikan kontribusi dirinya ataupun masyarakat diadopsi dari USOE, 1972 (dalam Sholeh 1998). Sidney P. Marland dari United States Commisision of Education (dalam Semiawan, 1995) menyatakan bahwa anak berbakat (gifted and talented) adalah mereka yang diidentifikasikan oleh orang-orang yang berkualifikasi profesional memiliki kemampuan luar biasa (unggul) sehingga mampu mencapai prestasi tinggi. Keberbakatan biasanya terbagi dalam tiga kategori (menurut skala Weschler) yakni: 1) Keberbakatan ringan adalah mereka yang memiliki IQ $=115-129,2) \mathrm{Ke}-$ berbakatan sedang adalah mereka yang memiliki $\mathrm{IQ}=130-144,3)$ Keberbakatan tinggi adalah mereka yang memiliki IQ $=145$ ke atas.

Marland (dalam Mulyoto, 2000) menyatakan bahwa anak berbakat (gifted) adalah mereka yang memiliki kemampuan serta kecakapan luar biasa dalam menyelesaikan pekerjaan-pekerjaan berkualitas tinggi dan secara potensial memiliki: 1) Kecakapan intelektual umum (intelegensi tinggi), 2) Kecakapan akademik khusus (matematika, bahasa, keilmuan, dsb), 3) Kreatif dan produktif dalam berfikir, 4) Kecakapan dalam kepemimpinan, 5) Kecakapan dalam bidang seni visual, 6) Kecakapan dalam aktivitas motorik.

Gagne (dalam Sholeh,1998) berpendapat bahwa keberbakatan (giftedness) adalah kemampuan alami (natural ability) atau bakat (aptitudes), sedangkan talent merupakan kemampuan yang telah dikembangkan (developed abilities) atau keterampilan (skill). Sementara itu Mary Meeker sebagaimana dikutip (dalam Sholeh, 
1998) mengemukakan bahwa ada tiga aspek untuk menentukan sikap gifted seseorang. Aspek I mencakup akademik, intelegensi, bahasa, dan linguistic. Aspek II mencakup emosi, kemampuan menyesuaikan diri dengan lingkungan sosialnya, serta motivasi. Aspek III mencakup psikologis, psikomotor dan perkembangan motorik.

Taylor (dalam Hawadi, 2004), menyatakan bahwa anak berbakat (gifted) ditujukan pada mereka yang mempunyai keunggulan dalam bidang akademik, kreativitas, perencanaan, komunikasi, kemampuan melihat ke depan, dan kemampuan mengambil keputusan. Selanjutnya, Renzulli (1986) berpendapat bahwa keberbakatan merupakan interaksi dari tiga kelompok ciri (cluster) yaitu: intelegensi, kreativitas, dan pengikatan diri (commitment) yang tinggi terhadap tugas dalam mencapai produktivitas. Pendapat tersebut dikenal sebagai konsepsi tiga lingkaran (The Three Rings Conception of Giftedness). Model Renzulli ini selanjutnya dilukiskan sebagai berikut (Renzulli, 1986).

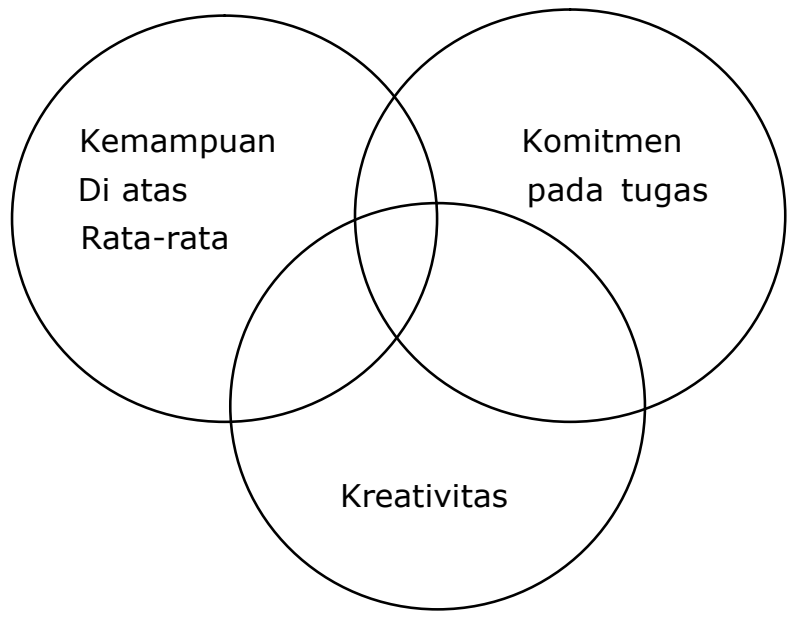

Gambar 1. Model Renzulli

Menurut Renzulli (1986) yang dimaksud dengan kemampuan (ability) adalah kecerdasan yang biasa diukur dengan tes-tes inteligensi. Seseorang yang memiliki IQ di atas rata-rata dapat disebut sebagai anak berbakat intelektual. Sementara itu, mengenai kreativitas terdiri atas bakat kreatif dan sikap kreatif. Seseorang yang memiliki CQ (Creativity Quotient) di atas rata-rata disebut sebagai anak yang kreatif. Untuk mengetahui tingkat kreativitas anak dapat diukur dengan menggunakan tes kreativitas verbal maupun figural. Sedangkan komitmen terhadap tugas (task commitment) adalah kesediaan dan kekuatan motivasi anak dalam mengikuti dan menyelesaikan berbagai tugas yang diberikan. Seseorang yang memiliki motivasi kuat untuk belajar, diduga akan semakin bertanggung jawab dalam menyelesaikan tugas-tugas yang berkaitan dengan belajar. Ketiga komponen itulah yang dapat digunakan untuk menentukan apakah seseorang dapat dimasukkan ke dalam program akselerasi atau tidak.

\section{Karakteristik Anak Berbakat}

Anak-anak berbakat istimewa secara alami memiliki karakteristik yang khas yang membedakannya dengan anak-anak normal. Karakteristik ini mencakup beberapa domain penting, termasuk di dalamnya domain intelektualkognitif, domain persepsi-emosi, domain motivasi dan nilai-nilai hidup, domain aktifitas, serta domain relasi sosial. Berikut disarikan beberapa karakteristik yang paling sering diidentifikasi terdapat pada anak berbakat istimewa pada masing-masing domain di atas. Namun demikian perlu dicatat bahwa tidak semua anak-anak berbakat istimewa ( gifted) selalu menunjukkan atau memiliki semua karakteristik yang disebutkan di dalam daftar ini (dikutip dari http:// giftedindonesia.wordpress.com, Welcome to the Gifted World, edisi April 2008, diunduh tanggal 26 Juni 2008).

\section{Karakteristik Intelektual-Kognitif}

1. Menunjukkan atau memiliki ide-ide yang orisinal, gagasan-gagasan yang tidak lazim, pikiran-pikiran kreatif.

2. Mampu menghubungkan ide-ide yang nampak tidak berkaitan menjadi suatu konsep yang utuh.

3. Menunjukkan kemampuan bernalar yang sangat tinggi.

4. Mampu menggeneralisir suatu masalah yang rumit menjadi suatu hal yang sederhana dan mudah dipahami.

5. Memiliki kecepatan yang sangat tinggi dalam memecahkan masalah.

6. Menunjukkan daya imajinasi yang luar biasa.

7. Memiliki perbendaharaan kosakata yang sangat kaya dan mampu mengartikulasikannya dengan baik. 
8. Biasanya fasih dalam berkomunikasi lisan, senang bermain atau merangkai kata-kata.

9. Sangat cepat dalam memahami pembicaraan atau pelajaran yang diberikan.

10. Memiliki daya ingat jangka panjang (long term memory) yang kuat.

11. Mampu menangkap ide-ide abstrak dalam konsep matematika dan/atau sains.

12. Memiliki kemampuan membaca yang sangat cepat.

13. Banyak gagasan dan mampu menginspirasi orang lain.

14. Memikirkan sesuatu secara kompleks, abstrak, dan dalam.

15. Mampu memikirkan tentang beragam gagasan atau persoalan dalam waktu yang bersamaan dan cepat mengaitkan satu dengan yang lainnya.

\section{Karakteristik Persepsi/Emosi}

1. Sangat peka perasaannya.

2. Menunjukkan gaya bercanda atau humor yang tidak lazim (sinis, tepat sasaran dalam menertawakan sesuatu hal tapi tanpa terasa dapat menyakiti perasaan orang lain).

3. Sangat perseptif dengan beragam bentuk emosi orang lain (peka dengan sesuatu yang tidak dirasakan oleh orang-orang lain).

4. Memiliki perasaan yang dalam atas sesuatu.

5. Peka dengan adanya perubahan kecil dalam lingkungan sekitar (suara, aroma, cahaya).

6. Pada umumnya introvert.

7. Memandang suatu persoalan dari berbagai macam sudut pandang.

8. Sangat terbuka dengan pengalaman atau hal-hal baru

9. Alaminya memiliki ketulusan hati yang lebih dalam dibanding anak lain.

\section{Karakteristik Motivasi Dan Nilai-Nilai Hidup}

1. Menuntut kesempurnaan dalam melakukan sesuatu (perfectionistic).

2. Memiliki dan menetapkan standar yang sangat tinggi bagi diri sendiri dan orang lain.

3. Memiliki rasa ingin tahu dan kepenasaran yang sangat tinggi.
4. Sangat mandiri, sering merasa tidak perlu bantuan orang lain, tidak terpengaruh oleh hadiah atau pujian dari luar untuk melakukan sesuatu (self driven).

5. Selalu berusaha mencari kebenaran, mempertanyakan dogma, mencari makna hidup.

6. Melakukan sesuatu atas dasar nilai-nilai filsafat yang seringkali sulit dipahami orang lain.

7. Senang menghadapi tantangan, pengambil risiko, menunjukkan perilaku yang dianggap "nyerempet-nyerempet bahaya" .

8. Sangat peduli dengan moralitas dan nilai-nilai keadilan, kejujuran, integritas.

9. Memiliki minat yang beragam dan terentang luas.

\section{Karakteristik Aktivitas}

1. Punya energi yang seolah tak pernah habis, selalu aktif beraktivitas dari satu hal ke hal lain tanpa terlihat lelah.

2. Sulit memulai tidur tapi cepat terbangun, waktu tidur yang lebih sedikit dibanding anak normal.

3. Sangat waspada.

4. Rentang perhatian yang panjang, mampu berkonsentrasi pada satu persoalan dalam waktu yang sangat lama.

5. Tekun, gigih, pantang menyerah.

6. Cepat bosan dengan situasi rutin, pikiran yang tidak pernah diam, selalu memunculkan halhal baru untuk dilakukan.

7. Spontanitas yang tinggi.

\section{Karakteristik Relasi Sosial}

1. Umumnya senang mempertanyakan atau menggugat sesuatu yang telah mapan.

2. Sulit melakukan kompromi dengan pendapat umum.

3. Merasa diri berbeda, lebih maju dibanding orang lain, merasa sendirian dalam berpikir atau pada saat merasakan suatu bentuk emosi.

4. Sangat mudah jatuh iba, empatik, senang membantu. 
5. Lebih senang dan merasa nyaman untuk berteman atau berdiskusi dengan orangorang yang usianya jauh lebih tua.

\section{Pengertian Program Akselerasi}

Secara konseptual, pengertian 'acceleration' diberikan oleh Pressy dalam Hawadi (2004) sebagai suatu kemajuan yang diperoleh dalam program pengajaran, pada waktu yang lebih cepat atau usia yang lebih muda daripada yang konvensional. Dalam program percepatan belajar untuk SD, SLTP dan SMA yang dicanangkan oleh pemerintah pada tahun 2000, akselerasi didefinisikan sebagai salah satu bentuk pelayanan pendidikan yang diberikan bagi siswa dengan kecerdasan dan kemampuan luar biasa untuk dapat menyelesaikan pendidikan lebih awal dari waktu yang telah ditentukan (Depdiknas, 2003).

Model penyelenggaraan program akselerasi ada bermacam-macam. Southern dan Jones (1991), menjelaskan sekurang-kurangnya ada 13 tipe/pola penyelenggaraan program akselerasi. Beberapa di antaranya adalah: 1) early entrance, siswa masuk sekolah dalam usia yang lebih muda dari persyaratan yang ditentukan pada umumnya; 2) grade skipping, siswa dipromosikan ke kelas yang lebih tinggi dari penempatan kelas yang normal pada akhir tahun pelajaran; 3) continous progress, siswa diberi materi pelajaran yang dianggap sesuai dengan prestasi yang mampu dicapainya; 4) subject matter acceleration, siswa ditempatkan dalam kelas yang lebih tinggi khusus untuk satu atau beberapa mata pelajaran; 5) curriculum compacting, siswa melaju pesat melalui kurikulum yang dirancang dengan mengurangi sejumlah aktivitas, seperti drill dan review; 6) telescoping curriculum, siswa menggunakan waktu yang kurang dari biasanya dengan menyelesaikan studi. Dari beberapa model tersebut, pada saat ini di Indonesia lebih dekat ke model yang keenam, telescoping curriculum.

Colangelo (dalam Depdiknas, 2003) menyebutkan bahwa istilah akselerasi menunjuk pada pelayanan yang diberikan (service delivery) dan kurikukum yang disampaikan (curriculum delivery). Sebagai model pelayanan, pengertian akselerasi termasuk juga taman kanak-kanak atau perguruan tinggi pada usia muda, meloncat kelas, dan mengikuti pelajaran tertentu pada kelas di atasnya. Sebagai model kurikulum, akselerasi berarti mempercepat bahan ajar dari yang seharusnya dikuasai oleh siswa saat itu. Hallahan dan Kaufman (2006) menyatakan bahwa program percepatan (acceleration) adalah pemberian layanan pendidikan sesuai potensi kecerdasan dan bakat istimewa yang dimiliki oleh siswa, dengan memberi kesempatan kepada mereka untuk dapat menyelesaikan program reguler dalam jangka waktu yang lebih singkat dibanding teman-temannya.

Sementara itu dalam implementasinya, Clark dalam Sholeh (1998) mengelompokkan bentuk penyelenggaraan program akselerasi menjadi 1 ) Kelas Reguler di mana siswa yang memiliki potensi kecerdasan dan bakat istimewa tetap berada bersama-sama dengan siswa lainnya di kelas reguler (model inklusi); 2) Kelas khusus, di mana siswa yang memiliki potensi kecerdasan dan bakat istimewa belajar dalam kelas khusus dan; 3) Sekolah khusus, di mana semua siswa yang belajar di sekolah ini adalah siswa yang memiliki potensi kecerdasan dan bakat istimewa.

\section{Efektivitas Penyelenggaraan Program akselerasi}

Pengertian efektif mengandung unsur nilai dari pelaksanaan suatu kegiatan. Nilai tersebut dapat dilihat dari nilai ekonomis, pendidikan maupun sosial psikologis. Nilai ekonomis suatu kegiatan dapat diukur dengan menggunakan rumus: $\mathrm{E}=$ $\mathrm{M}-\mathrm{L}$ (efektif = pemasukan dikurangi pengeluaran). Jika antara pemasukan dengan pengeluaran tidak sebanding maka kegiatan itu tidak efektif dan sebaliknya.

Dalam kajian ini pengukuran efektif tidaknya program akselerasi akan diukur dari aspek manajemen penyelenggaraan. Indikator-indikator manajemen program akselerasi dikembangkan mulai dari persiapan, rekruitmen, kurikulum, pembelajaran, aspek guru, orangtua, sarana dan prasarana dan seterusnya sampai aspek evaluasi dan tindak lanjut. Dari indikator tersebut selanjutnya digunakan untuk melakukan pengamatan dengan kondisi yang berjalan, sehingga diperoleh gambaran mana kegiatan yang berjalan dan mana yang belum berjalan.

Efektivitas dari aspek pendidikan dapat digunakan formula: $\mathrm{E}=(\mathrm{HBA}: \mathrm{HBNA})$. Efektif adalah 
perbandingan atas hasil belajar akseleran dengan hasil belajar nonakseleran. Jika hasil belajar anakanak akseleran lebih baik atau sekurangkurangnya sama dari hasil belajar anak-anak nonakseleran, maka program tersebut efektif dan sebaliknya. Dalam penelitian ini hasil belajar tidak dikaji secara khusus, tetapi yang dikaji adalah aspek rekruitmen. Disebut efektif jika hasil seleksi calon peserta program akselerasi sama atau lebih tinggi dari criteria normatif standar minimal siswa yang bisa diterima di kelas akselerasi.

Sementara itu, efektivitas dilihat dari nilai beberapa aspek kepribadian siswa dapat dirumuskan sebagai berikut: $E=(K K A: K K S)$. Efektif adalah perbandingan Kondisi Kepribadian Awal (KKA) dengan Kondisi Kepribadian Saat ini atau sekarang (KKS). Jika skor kepribadian awal lebih buruk dari skor kepribadian saat ini, berarti program akselerasi berdampak positif bagi perubahan beberapa aspek kepribadian siswa akseleran. Beberapa aspek kepribadian yang akan dibandingkan meliputi aspek motivasi berprestasi/belajar, konsep diri dan kemandirian anak.

Untuk mengetahui efektivitas program akselerasi juga dapat dilihat dari aspek tenaga guru. Sikap guru terhadap program akselerasi merupakan faktor yang penting dan diduga ikut berpengaruh terhadap keberhasilan pembelajaran yang digunakan oleh guru. Untuk itu maka dalam kajian ini sikap guru terhadap program akselerasi akan dibandingkan antara guru yang mengajar di kelas akselerasi dengan guru yang tidak mengajar di kelas akselerasi. Jika sikap guru pada kelas akselerasi lebih positif dibanding dengan sikap guru nonkelas akselerasi, berarti program akselerasi termasuk efektif.

\section{Hipotesis Kerja}

Sesuai dengan permasalahan penelitian dan hasil kajian teoritik secara singkat dapat disusun suatu hipotesis kerja sebagai berikut: 1) Pengelolaan program akselerasi di SMA telah dijalankan dengan baik; 2) Proses rekruitmen calon peserta program akselerasi dilaksanakan secara efektif; 3) Motivasi berprestasi siswa program akselerasi termasuk kategori tinggi; 4) Program akselerasi berdampak positif terhadap perkembangan kepribadian siswa; 5) Respon guru yang mengajar di kelas akselerasi lebih positif dibandingkan dengan sikap guru yang tidak mengajar di kelas akselerasi.

\section{Metode Penelitian}

Penelitian ini termasuk jenis deskriptif kuantitatif. Hal-hal yang akan dideskripsikan meliputi aspek pengelolaan program, aspek rekruitmen, aspek motivasi, aspek dampak kepribadian dan aspek respon guru. Tiga metode yang digunakan dalam pengumpulan data, yaitu: 1) Metode dokumentasi, metode ini akan digunakan untuk melihat aspek manajemen penyelenggaraan, data profil psikologis anak berdasarkan hasil tes psikologi saat penjaringan dan penyaringan; 2) Metode Angket, metode ini akan digunakan untuk mengetahui gambaran tentang motivasi Belajar, kepercayaan diri dan konsep diri anak; 3) Metode wawancara/diskusi terfokus, metode wawancara/ diskusi terfokus akan digunakan jika data kuantitatif sesuai dengan tujuan penelitian dirasa belum tercukupi, yaitu untuk melengkapi temuantemuan deskriptif yang ada. Wawancara terutama ditujukan kepada penyelenggara program.

Subjek penelitian adalah semua siswa peserta program akselerasi di SMA X. Jumlah peserta program adalah 59 anak (2 kelas). Sementara itu, untuk sample guru masing-masing kelompok (guru kelas akselerasi) 25 orang dan (guru kelas non akselerasi) 25 orang dipilih secara random kelas. Data yang terkumpul dianalisis dengan menggunakan analisis statistik deskriptif tabulasi silang, sedangkan data pendukung dilakukan analisis kualitatif.

\section{Hasil Penelitian dan Bahasan}

\section{Tentang Manajemen Pengelolaan Program Akselerasi}

Berdasarkan dokumen yang diperoleh dari penyelenggara terutama bersumber dari proposal yang diajukan kepada pemerintah pada saat pengajuan rencana penyelenggaraan program akselerasi serta laporan kegiatan yang dibuat oleh pihak penyelenggara, disajikan pada Tabel 1 . 
Tabel 1. Pengelolaan Program Akselerasi di SMA Surakarta

\begin{tabular}{|c|c|c|c|c|}
\hline No & Aspek Yang Diamati & $\begin{array}{c}\text { Ada/ } \\
\text { Ya }\end{array}$ & $\begin{array}{l}\text { Tidak } \\
\text { Ada }\end{array}$ & Keterangan \\
\hline 1 & $\begin{array}{l}\text { Aspek Legalitas } \\
\text { Penyelenggaraan/Dasar Hukum } \\
\text { 1. Tingkat Nasional } \\
\text { 2. Tingkat Provinsi } \\
\text { 3. Tingkat Kota }\end{array}$ & $\mathrm{V}$ & V & $\begin{array}{l}\text { Dalam bentuk surat persetujuan } \\
\text { Kepala Dinas Pendidikan dan } \\
\text { Kebudayaan Provinsi. SK Dirjen } \\
\text { belum ada. }\end{array}$ \\
\hline 2 & $\begin{array}{l}\text { Aspek Organisasi dan personalia } \\
\text { penyelenggara : } \\
\text { 1. Struktur organisasi } \\
\text { 2. Personalia }\end{array}$ & $\begin{array}{l}\mathrm{V} \\
\mathrm{V}\end{array}$ & & $\begin{array}{l}\text { Telah ditetapkan tim pengelola } \\
\text { program dipimpin oleh seorang } \\
\text { Koordinator dibawah Kepala Sekolah. }\end{array}$ \\
\hline \multirow[t]{5}{*}{3} & $\begin{array}{l}\text { Aspek Rekruitmen calon peserta } \\
\text { program }\end{array}$ & & & \multirow{5}{*}{$\begin{array}{l}\text { Tes dilakukan hanya kepada yang } \\
\text { memiliki nilai NEM SMP tinggi. Tes } \\
\text { akademik lain adalah B. Inggris. }\end{array}$} \\
\hline & 1. Tes IQ, CQ, dan TC dan tes lain & $\mathrm{V}$ & & \\
\hline & 2. Tester professional/independen & $\mathrm{V}$ & & \\
\hline & 3. Data tertulis hasil tes psikologis & $\mathrm{V}$ & & \\
\hline & 4. Tes akademik yang lain & $\mathrm{V}$ & & \\
\hline \multirow[t]{4}{*}{4} & Aspek Guru & & & \\
\hline & 1. Semua calon guru ditatar khusus & & $\mathrm{V}$ & $\begin{array}{l}\text { Hanya sosialisasi, ada sebagian yang } \\
\text { ditatar setelah program berjalan. }\end{array}$ \\
\hline & 2. Calon guru diseleksi khusus & & $\mathrm{V}$ & Sesuai kebutuhan \\
\hline & 3. Tambahan insentif guru & $\mathrm{V}$ & & \\
\hline \multirow[t]{5}{*}{5} & Aspek Orangtua Anak : & & & \\
\hline & 1. Keterlibatan OT saat seleksi & $\mathrm{V}$ & & Melalui wawancara \\
\hline & $\begin{array}{l}\text { 2. Keterlibatan OT saat proses pendidikan } \\
\text { berjalan }\end{array}$ & $\mathrm{V}$ & & $\begin{array}{l}\text { Terutama bagi anak yang } \\
\text { memerlukan bimbingan khusus }\end{array}$ \\
\hline & 3. Keterlibatan OT saat evaluasi & & $\mathrm{V}$ & \\
\hline & $\begin{array}{l}\text { 4. Orangtua yang melakukan komplain ke } \\
\text { sekolah }\end{array}$ & & $\mathrm{V}$ & $\begin{array}{l}\text { Yang sifatnya masukan ada } \\
\text { beberapa, jadi bukan komplein. }\end{array}$ \\
\hline \multirow[t]{6}{*}{6} & Aspek Kurikulum Yang digunakan & & & \\
\hline & 1. Dibentuk Tim penyusun kurikulum khusus & & $\mathrm{V}$ & $\begin{array}{l}\text { Yang ada berupa program intra dan } \\
\text { ekstra kurikuler }\end{array}$ \\
\hline & 2. Jadwal khusus intra kurikuluer & $\mathrm{V}$ & & \\
\hline & 3. Jadwal khusus ekstra kurikuler & $\mathrm{V}$ & & \\
\hline & $\begin{array}{l}\text { 4. Evaluasi kurikulum secara khusus oleh } \\
\text { pihak luar dan dalam }\end{array}$ & & $\mathrm{V}$ & Hanya berdasarkan pengalaman \\
\hline & 5. Pengesahan Kurikulum khusus & & $\mathrm{V}$ & $\begin{array}{l}\text { Ada tetapi hanya oleh Kepala } \\
\text { Sekolah, berupa program. }\end{array}$ \\
\hline \multirow[t]{6}{*}{7} & $\begin{array}{l}\text { Aspek Pembelajaran Yang Digunakan } \\
\text { Guru : }\end{array}$ & & & \\
\hline & 1. Penggunaan teknologi informasi & $\mathrm{V}$ & & \\
\hline & 2. Pemanfaatan perpustakaan & $\mathrm{V}$ & & \\
\hline & 3. Pemanfaatan laboratorium & $\mathrm{V}$ & & \\
\hline & $\begin{array}{l}\text { 4. Monitoring dan evaluasi pembelajaran } \\
\text { guru }\end{array}$ & & $\mathrm{V}$ & \\
\hline & $\begin{array}{l}\text { 5. Tersedia panduan pembelajaran khusus } \\
\text { bagi kelas akselerasi }\end{array}$ & & $\mathrm{V}$ & \\
\hline \multirow[t]{7}{*}{8} & Aspek Evaluasi Pembelajaran : & & & \\
\hline & 1. Tes tengah semester & $\mathrm{V}$ & & \\
\hline & 2. Tes akhir semester & $\mathrm{V}$ & & \\
\hline & 3. Tes kegiatan ekstra kurikuler & $\mathrm{V}$ & & $\begin{array}{l}\text { Antara lain presentasi kegiatan } \\
\text { penelitian siswa, penulisan makalah, } \\
\text { dll. }\end{array}$ \\
\hline & 4. Hasil tes memuaskan & $\mathrm{V}$ & & Lebih dari $90 \%$ memuaskan \\
\hline & 5. hasil tes yang kurang memuaskan & $\mathrm{V}$ & & $\begin{array}{l}\text { Ada beberapa anak yang berada di } \\
\text { bawah rata-rata target sekolah, } \\
\text { tetapi telah dilakukan pembinaan. }\end{array}$ \\
\hline & 6. Anak yang pindah ke reguler & & $\mathrm{V}$ & $\begin{array}{l}\text { Semua naik ke kelas II program } \\
\text { akselerasi }\end{array}$ \\
\hline
\end{tabular}




\begin{tabular}{|c|c|c|c|c|}
\hline \multirow[t]{8}{*}{9} & Aspek Tindak Lanjut & & & \\
\hline & 1. Menganalisis data hasil tahun I & & $\mathrm{V}$ & \\
\hline & $\begin{array}{l}\text { 2. Mengevaluasi efektivitas dan dampak } \\
\text { program bagi stake holders. }\end{array}$ & & $\mathrm{V}$ & \\
\hline & 3. Lokakarya Evaluasihasil tahun I & & $\mathrm{V}$ & \\
\hline & 4. Perbaikan program & $\mathrm{V}$ & & \\
\hline & 5. Laporan hasil tahun I & $\mathrm{V}$ & & $\begin{array}{l}\text { Terbatas ke Tingkat Kota dan } \\
\text { Provinsi }\end{array}$ \\
\hline & 6. Komunikasi dengan orangtua & $\mathrm{V}$ & & \\
\hline & 7. Komunikasi dengan guru & & $\mathrm{V}$ & $\begin{array}{l}\text { Terbatas dalam rapat-rapat } \\
\text { koordinasi. }\end{array}$ \\
\hline \multirow[t]{5}{*}{10} & $\begin{array}{l}\text { Aspek Kepuasan Pelanggan Atas } \\
\text { pelaksanaan program : }\end{array}$ & & & \\
\hline & 1. Pengukuran Kepuasan orangtua & & $\mathrm{V}$ & \\
\hline & 2. Pengukuran Kepuasan anak & & $\mathrm{V}$ & \\
\hline & 3. Pengukuran Kepuasan guru & & $\mathrm{V}$ & \\
\hline & 4. Pengukuran kepuasan masyarkt. & & $\mathrm{V}$ & \\
\hline \multirow[t]{4}{*}{11} & Lain-lain : & & & \\
\hline & $\begin{array}{l}\text { 1. Ketersediaan sarana dan prasarana } \\
\text { pendukung program }\end{array}$ & V & & \\
\hline & 2. Peran Komite Sekolah & $\mathrm{V}$ & & \\
\hline & 3. Permasalahan yang muncul & V & & $\begin{array}{l}\text { Pada umumnya semua permasalahan } \\
\text { dapat diatasi dengan baik. }\end{array}$ \\
\hline
\end{tabular}

Berdasarkan Tabel 1 dapat diketahui bahwa dari sisi manajemen penyelenggaraan program hampir semua komponen dari input, proses dan output telah tersedia pendukung kegiatan yang memadai. Meskipun demikian masih tampak beberapa aspek yang perlu mendapatkan perhatian terutama komponen yang bertanda 'tidak ada'. Hal-hal yang kurang sesuai atau belum memenuhi standar ideal antara lain adalah aspek legalitas di tingkat pusat, rekuitmen calon guru, penataran guru, tim penyusun kurikulum, evaluasi kurikulum, pengesahan kurikulum, monitoring pembelajaran, penyusunan panduan pembelajaran, tindak lanjut evaluasi, serta analisis terhadap kepuasan pelanggan. Jika hal-hal tersebut dapat dilakukan tentu akan sangat menunjang perbaikan penyelenggaraan program akselerasi di SMA Surakarta.

\section{Tentang Rekruitmen Calon Peserta Program Akselerasi}

Berdasarkan data dokumen hasil seleksi calon peserta program akselerasi siswa SMA angkatan I tahun 2003/2004, dapat dilihat pada Tabel 2.

Kesesuaian antara rekomendasi psikolog dengan keputusan tentang penetapan peserta yang dinyatakan diterima sebagai peserta program akselerasi.

Tabel 2. Klasifikasi dan Kategori Hasil Seleksi Peserta Program Akselerasi

\begin{tabular}{|c|c|c|c|c|c|}
\hline \multirow[t]{2}{*}{ No } & \multirow[t]{2}{*}{ Aspek } & \multicolumn{3}{|c|}{ Kategori/Klasifikasi } & \multirow{2}{*}{$\begin{array}{c}\text { Keterangan } \\
\text { (jumlah) }\end{array}$} \\
\hline & & Tinggi & Sedang & Rendah & \\
\hline 1 & $\begin{array}{l}\text { Kecerdasan } \\
\text { (IQ) }\end{array}$ & $\begin{array}{c}11 \\
(18,64 \%)\end{array}$ & $\begin{array}{c}32 \\
(54,24 \%) \\
\end{array}$ & $\begin{array}{c}16 \\
(27,12 \%)\end{array}$ & $\begin{array}{c}59 \\
(100 \%)\end{array}$ \\
\hline 2 & $\begin{array}{l}\text { Kreativitas } \\
\text { (CQ) }\end{array}$ & $\begin{array}{c}3 \\
(5,08 \%)\end{array}$ & $\begin{array}{c}41 \\
(69,49 \%) \\
\end{array}$ & $\begin{array}{c}15 \\
(25,42 \%) \\
\end{array}$ & $\begin{array}{c}59 \\
(100 \%)\end{array}$ \\
\hline 3 & $\begin{array}{l}\text { Tanggung } \\
\text { Jawab (TC) }\end{array}$ & $\begin{array}{c}14 \\
(23,72 \%)\end{array}$ & $\begin{array}{c}42 \\
(71,19 \%)\end{array}$ & $\begin{array}{c}3 \\
(5,08 \%)\end{array}$ & $\begin{array}{c}59 \\
(100 \%)\end{array}$ \\
\hline
\end{tabular}

Catatan: Kriteria tinggi, sedang, rendah adalah untuk ukuran anak berbakat yaitu:

1. IQ tinggi: $>125$, sedang $120-124$, rendah $<120$

2. CQ tinggi (B), sedang (S), rendah (K)

3. TC tinggi $(B)$, sedang $(S)$, rendah $(K)$ 
Tabel 3. Rekomendasi psikologi dan penerimaan siswa

\begin{tabular}{|l|l|c|c|}
\hline No & \multicolumn{1}{|c|}{ Rekomendasi } & $\begin{array}{c}\text { Jumlah } \\
\text { (frekuensi) }\end{array}$ & Prosen (\%) \\
\hline 1 & Dapat Disarankan Diterima (DD) & 42 & $71,19 \%$ \\
\hline 2 & $\begin{array}{l}\text { Dapat Disarankan Diterima dengan } \\
\text { Pertimbangan (DDP) }\end{array}$ & 16 & $27,19 \%$ \\
\hline 3 & Belum Disarankan Diterima (BD) & 1 & $1,62 \%$ \\
\hline
\end{tabular}

Berdasarkan Tabel 2 dan Tabel 3 di atas, diketahui bahwa 1) Sebagian besar siswa akseleran di SMA memiliki skor IQ kategori sedang $(54,24 \%), 2)$ Sebagian besar siswa akseleran di SMA memiliki skor CQ kategori sedang $(69,49 \%)$, 3) Sebagian besar siswa akseleran di SMA memiliki skor TC kategori sedang (71,19\%), 4) Dari 59 siswa akseleran di SMA yang memenuhi kriteria normatif ada 42 siswa (71,19\%), disarankan dengan pertimbangan (DDP) 16 siswa (27,19\%), dan Belum Disarankan (BD) 1 siswa $(1,6 \%)$.

\section{Motivasi Berprestasi}

Motivasi berprestasi merupakan faktor penting bagi keberhasilan belajar (prestasi belajar). Hasil tabulasi data atas kuesioner motivasi yang disampaikan kepada peserta program akselerasi, disajikan pada Tabel 4.
Berdasarkan Tabel 4, tampak bahwa ada perbedaan tingkat motivasi berprestasi antara kelas A dan B. Untuk kelas A cenderung tinggi (64\%) untuk skala motivasi bagian 1 , sedangkan bagian 2 cenderung sedang (96\%). Sementara itu, untuk kelas B cenderung sedang, baik untuk skala motivasi bagian 1 maupun bagian 2. masingmasing $60 \%$ dan $84 \%$.

\section{Dampak Program Akselerasi}

Untuk mengetahui dampak program akselerasi dikembangkan inventori untuk mengetahui perbedaan beberapa aspek kepribadian siswa antara kondisi di awal program dengan kondisi sekarang setelah berjalan satu tahun. Waktu satu tahun dianggap telah cukup untuk mengukur perbedaan kondisi psikologis siswa. Beberapa aspek yang diungkap dalam kepribadian siswa meliputi konsep diri dan kepercayaan diri, disajikan pada Tabel 5 .

Tabel 4. Skor Kategori Motivasi Belajar Siswa Akselerasi

\begin{tabular}{|c|l|c|c|c|}
\hline No & \multicolumn{1}{|c|}{ Siswa Kelas } & \multicolumn{2}{|c|}{ Kategori } \\
\cline { 3 - 5 } & & $\begin{array}{c}\text { Tinggi } \\
\text { (jml dan \%) }\end{array}$ & $\begin{array}{c}\text { Sedang } \\
\text { (jml dan \%) }\end{array}$ & $\begin{array}{c}\text { Rendah } \\
\text { (jml dan \%) }\end{array}$ \\
\hline 1 & Kelas A & $16(64 \%)$ & $9(36 \%)$ & - \\
\hline & (1) Skor Tes Bagian 1 & $1(4 \%)$ & $24(96 \%)$ & - \\
\hline & (2) Skor Tes Bagian 2 & & $15(60 \%)$ & 1 \\
\hline 2 & Kelas B & $9(36 \%)$ & $21(84 \%)$ & $(4 \%)$ \\
\hline & (1) Skor Tes Bagian 1 & $4(16 \%)$ & & - \\
\hline
\end{tabular}

Catatan: $\mathrm{N}=$ untuk masing-masing kelas tidak sama.

Tabel 5. Perbedaan Skor Tes Kepribadian Awal dan Akhir Program Akselerasi

\begin{tabular}{|l|l|c|c|c|c|}
\hline No & Kelas & $\begin{array}{c}\text { Rata-rata Skor } \\
\text { Awal }\end{array}$ & $\begin{array}{c}\text { Rata-rata Skor } \\
\text { Akhir }\end{array}$ & $\begin{array}{c}\text { Jumlah (+) } \\
\text { dan \% }\end{array}$ & $\begin{array}{c}\text { Jumlah } \\
\text { dan } \%\end{array}$ \\
\hline 1 & Kelas A & 2,53 & 2,88 & $15(60 \%)$ & $8(32 \%)$ \\
\hline 2 & Kelas B & 2,78 & 3,02 & $20(80 \%)$ & $3(12 \%)$ \\
\hline Jumlah Skor & $\mathbf{5 , 3 1}$ & $\mathbf{5 , 9}$ & $\mathbf{3 5}$ & $\mathbf{1 1}$ \\
\hline \multicolumn{2}{|l|}{ Rata-rata (2 kelas) } & $\mathbf{2 , 6 5}$ & $\mathbf{2 , 9 5}$ & $\mathbf{1 7 , 5}$ & $\mathbf{5 , 5}$ \\
\hline
\end{tabular}


Dari Tabel 5 di atas dapat diketahui bahwa 1) Program akselerasi berdampak positif terhadap aspek kemandirian dan konsep diri siswa, yaitu terjadi koreksi atas kemandirian dan konsep diri yang kurang baik di awal dengan rata-rata skor 2,65 kemudian naik menjadi 2,95 di akhir program, 2) Perubahan ini tidak hanya terjadi pada salah satu kelas tetapi juga kedua kelas, 3) Jumlah siswa yang mengalami kenaikan atau perubahan kepercayaan dan konsep diri untuk kelas A 60\% sedangkan kelas B $80 \%$, meng-isyaratkan bahwa program akselerasi berdampak positif terhadap perkembangan beberapa aspek kepribadian siswa.

\section{Tentang Sikap Guru}

Tentang sikap guru terhadap program akselerasi, dalam kajian ini dikelompokkan menjadi dua, yaitu guru yang mengajar di kelas akselerasi dan satu kelompok lain guru yang hanya mengajar di kelas reguler. Dari hasil pengumpulan data menggunakan angket, setelah diolah dengan menggunakan statistic disajikan pada Tabel 6 dan 7.

Tabel 6. Distribusi Frekuensi Skor Sikap Guru MP pada Kelas Akselerasi

\begin{tabular}{|c|c|c|}
\hline Interval & F. Absolut & Perseentase (\%) \\
\hline $110-119$ & 11 & 44 \\
\hline $120-129$ & 10 & 40 \\
\hline $130-139$ & 1 & 4 \\
\hline $140-149$ & 1 & 4 \\
\hline $150-159$ & 2 & 8 \\
\hline $160-169$ & 0 & 0 \\
\hline Jumlah & 25 & $100 \%$ \\
\hline
\end{tabular}

Tabel 7. Distribusi Frekuensi Skor Sikap Guru MP pada Kelas Reguler

\begin{tabular}{|c|c|c|}
\hline Interval & F. Absolut & $\begin{array}{c}\text { Persentase } \\
(\%)\end{array}$ \\
\hline $105-111$ & 11 & 44 \\
\hline $112-118$ & 9 & 36 \\
\hline $119-125$ & 1 & 4 \\
\hline $126-132$ & 3 & 12 \\
\hline $133-139$ & 0 & 0 \\
\hline $140-146$ & 1 & 4 \\
\hline Jumlah & 25 & $100 \%$ \\
\hline
\end{tabular}

Dari hasil analisis statistik atas data tersebut, diperoleh $p=0,0024<$ dari 0,05 sehingga Ho ditolak. Dengan demikian ada perbedaan secara signifikan antara sikap guru kelas akselerasi dengan sikap guru kelas reguler. Dengan kata lain guru-guru yang mengajar pada kelas akselerasi cenderung lebih bersikap positif daripada guru yang mengajar di kelas reguler. Dari temuan tersebut dapat diinterpretasikan bahwa program akselerasi berdampak terhadap sikap guru yang mengajar di kelas akselerasi.

\section{Simpulan dan Saran}

\section{Simpulan}

Dari hasil analisis data yang telah diuraikan sebelumnya dapat disimpulkan sebagai berikut. 1) Secara umum manajemen penyelenggaraan program akselerasi di SMAN X Surakarta, termasuk kategori baik. Meskipun ada beberapa aspek yang belum terpenuhi sesuai standar ideal, namun kekurangan tersebut tidak mengurangi kualitas proses dan manajemen penyelenggaraan program akselerasi secara keseluruhan, 2) Dari sisi proses rekruitmen, untuk angkatan pertama masih ada beberapa aspek yang belum memenuhi standar ideal, seperti siswa yang terjaring belum semuanya memiliki standar minimal skor tes $I Q$, $C Q$, dan TC yang dipersyaratkan. Dukungan data akademik lain seperti NEM, Raport, dan skor tes akademik, relatif sudah cukup baik sebagai bahan pertimbangan untuk penerimaan calon peserta program akselerasi. Secara umum rekruitmen masih menunjukkan perlunya perbaikan dan penyempurnaan, dan perbaikan itu ternyata telah dilakukan untuk seleksi angkatan kedua, 3) Efektivitas program akselerasi dilihat dari aspek motivasi berprestasi siswa akseleran ditemukan bahwa kelas A memiliki tingkat motivasi berprestasi yang lebih tinggi dari kelas B dengan perbandingan $72 \%$ dibanding $68 \%$. Namun skor gabungan seluruh peserta (59 siswa) menunjukkan bahwa antara yang memiliki motivasi berprestasi tinggi dengan yang sedang proporsinya seimbang masing-masing 50\%,4) Efektivitas program akselerasi dilihat dari aspek dampak terhadap berapa aspek kepribadian (kepercayaan dan konsep diri siswa), ditemukan bahwa lebih dari $60 \%$ siswa akselerasi kelas $A$ berdampak positif, 32\% negatif (menurun), dan $8 \%$ tetap. Sementara itu, untuk kelas B lebih dari $80 \%$ positif, $12 \%$ negatif (menurun) dan $8 \%$ tetap. Penelitian ini belum dapat mengungkapkan faktorfaktor penyebabnya, 5) Efektivitas program 
akselerasi dilihat dari aspek guru, dapat disimpulkan bahwa guru-guru yang mengajar di kelas akselerasi memiliki sikap yang lebih positif terhadap program akselerasi dibandingkan dengan guru-guru yang mengajar di kelas reguler. Meskipun hal ini ada faktor lain namun temuan ini secara statistik cukup signifikan.

\section{Saran}

Banyak hal yang dapat dilakukan oleh para peneliti yang tertarik di bidang pendidikan anak berbakat yang belum sempat mendapatkan kajian melalui penelitian ini. Beberapa aspek tersebut antara lain tentang perbandingan aspek-aspek psikologis antara akseleran dengan siswa reguler, perbandingan hasil belajar dengan siswa reguler, aspek emosional (EQ) dan spiritual (SQ), serta masalah cita-cita dan harapan di bidang pendidikan lanjut dan pilihan karier merupakan hal yang tidak kalah pentingnya untuk dikaji.

\section{Pustaka Acuan}

Departemen Pendidikan Nasional. Dirjen Pendidikan Dasar dan Menengah. 2003. Pedoman Penyelenggaraan Program Percepatan Belajar SD, SMP, dan SMA. Satu Model Pelayanan Pendidikan Bagi Peserta Didik Yang Memiliki Potensi Kecerdasan Dan Bakat Istimewa. Jakarta: Departemen Pendidikan Nasional. Dirjen Pendidikan Dasar dan Menengah.

Gardner, Howard. 1993. Frames of Mind: The Theory of Multiple Intelligences, New York: Basic Books. The second edition was published in Britain by Fontana Press. $466+$ xxix pages.

http://giftedindonesia.wordpress.com, Welcome to the Gifted World, edisi April 2008), diunduh pada tanggal 20 Juni 2008.

http://www.ditplb.or.id. 2006, Pedoman Penyelenggaraan Program Percepatan Belajar Bagi Siswa Berbakat Akademik, Drektorat Pembinaan Sekolah Luar Biasa, Depdiknas Jakarta. Diunduh pada tanggal 20 Juni 2008.

Hallahan, D.P. dan Kaufman J.M. 2006. Exceptional Learners: Introduction to Special Education, University of Virginia, Paige C. Pullen, ISBN-13: 9780205571048 Publisher: Merrill.

Hawadi, Reni Akbar. 2004, Program Percepatan Belajar bagi Anak Berbakat Intelektual Ditinjau dari Sisi Psikologis, dalam Reni Akbar Hawadi, Program Akselerasi, Jakarta, Grasindo, 2004.

Nasichin, 2004, Kebijakan Pemerintah dalam Pembinaan Sekolah Penyelenggara Program Percepatan Belajar, dalam Reni Akbar Hawadi, Akselerasi, Grasindo, 2004.

Renzulli, J.S. (Ed.) 1986. Systems and models for developing programs for the gifted and talented. Mansfield Center, CT: Creative Learning Press.

Sholeh, Moch. Y.A.I. 1998. Perspektif Pendidikan Anak Gifted. Jakarta: Departemen Pendidikan dan Kebudayaan.

Southern, W. Thomas and Jones E.D. 1991, The Academic Acceleration of Gofted Children, New York: Teacher College Press.

Undang-Undang Nomor 20 Tahun 2003 tentang Sistem Pendidikan Nasional. 2003. Jakarta: Departemen Pendidikan Nasional. 